\title{
Global Tourism and Terrorism. Safety and Security Management
}

\author{
Silvio M. Brondoni*
}

\begin{abstract}
In the last two years, some Mediterranean regions have obtained significant benefits from the contraction of large tourist investments marking contrasting trends, as in the case of Sardinia and other Italian and Spanish sub-regions (conceivably due to their perception as safer locations).

In global tourism, security and safety have become complex issues with a wide range of components including consumer protection, legal protection of tourists, environmental security, disaster protection, data safety, personal safety in communication, quality assurance of services.

The vulnerability of tourism to external negative events, such as tourism terrorism, has defined the increasing importance of tourism safety and security management in a global approach as an integral part of the tourism industry's operations.
\end{abstract}

Keywords: Global Markets; Global Tourism Management; Terrorism; Safety Management; Security Management

\section{Globalisation and Tourism Management}

Since the early 80s, globalization has profoundly changed tourism, which has become the single largest area of activity worldwide. The mobility of travellers and tourists has grown quickly over the years, on the one hand polarizing huge flows of mass tourism in Europe, on the other, marking the rapid growth of new destinations in Asia and the Pacific. In recent years, these new resorts have led to a significant decline in the traditional mass market share (Brondoni, 2016; Dwyer et al., 2008).

The traditional mass tourism model is characterized by a national producer's domination with offers that are usually standardized, very poor and without variety (Brondoni, 2015; Brondoni, 2014).

The progressive decline of large investments in traditional mass tourism can be attributed to numerous causes. First, the critical problems and instability related to terrorism, to migrants and political conflicts in many regions (e.g., North Africa, Turkey, Sun Belt) (Adejuwon, 1996). These factors have caused the stagnation of the traditional mass market in the Mediterranean (e.g., travellers from Northern Europe) and tend to be counteracted by the management and policies of global

\footnotetext{
* Full Professor of Management, University of Milan-Bicocca (silvio.brondoni@ unimib.it)
} 
companies with different location choices (outside of the Mediterranean) that modify primary demand for local tourism (Brondoni, 2016; Apostolopoulos \& Sönmez, 2000; Brackenbury, 1996). Indeed, the first terrorist acts devastated the Mediterranean area, but in more recent years have extended to other areas (e.g., Thailand), emphasizing on one hand, the close link between tourist investments and terrorism, and on the other, highlighting that global tourism has become a priority strategic objective, surpassing international finance (i.e., New York City and Washington, 11 September 2001) (Lambin, 2011).

In the last two years, some Mediterranean regions have obtained significant benefits from the contraction of large tourist investments marking contrasting trends, as in the case of Sardinia and other Italian and Spanish sub-regions. However, these phenomena appear to be primarily related to the movement of tourism flows (conceivably due to their perception as safer locations) rather than new tendencies of substantial investments in mass tourism based on specific destinations (traditional mass tourism) (Brondoni, 2016). Furthermore, the strong seasonal nature of tourism (over $40 \%$ of business is concentrated between June and September) explains the international investment choices in organized tourist resorts (locations and infrastructure) in, amongst others, Egypt, Tunisia and Turkey whose geographic locations enable extending the tourist season. These locations however are primary targets of dramatic terrorist acts, aimed at striking at the local tourism industry and hence international investments. In addition, in this case, management policies tend to take the form of new mass tourism proposals, directing new investments towards safer destinations and reducing investments in the regions under terrorist attacks. These new destinations derive from management policies developed by corporations according to a global competition approach, setting out to create and develop new global tourism segments (ecotourism, cultural tourism, extreme sports tourism, etc.) (Brondoni, 2016). Corporate global tourism policies therefore focus first on mass tourism products, creating a highly characteristic and volatile offer, abandoning the traditional residential tourism model to meet the new expectations (driven by the global mass media) of tourists and travellers based on specialty tourism drivers, particularly experience tourism and sensation tourism (Brondoni, 2012).

Differentiation of vacation types, the competitive proliferation of new destinations, the creation of demand bubbles in traveller preferences and the growth of softer forms of tourism (B\&B, rent-a-house, sharing accommodation, etc.) overall constitute new dimensions that stress the quality of the tourist experience. In this sense, the tourist area will acquire a premium image, generating economic results for durable tourism, while the sites and destinations will gain the attention of travellers (Brondoni, 2016; Bellini, 2004)

\section{Global Tourism and Terrorism}

At present, tourism is a global and intensely competitive industry, and for these reasons, tourism is highly sensitive to the perceptions of danger and lack of safety and security.

Safety and security have always been critical conditions for tourist and travellers. Since the ' 80 , safety and security issues have gained much greater importance. 
Terrorist acts, local wars, epidemics, and natural disasters have negative impacts and durable consequences on the travel and tourism industries and demonstrate the vulnerability of the tourism businesses on both the global and local level.

According to a World Travel and Tourism Council report, it takes about 13 months for tourism to recover from a terrorist attack. The study also found that by comparison, tourism takes longer to bounce back from disease (21 months), an environmental disaster (24 months), and political unrest (27 months) (Zillman, 2015).

$\square$ "How much does a tourist attack cost? According to the Time's estimate, the ISIL attack on Sousse in Tunisia produced a loss of $\$ 500$ million, a quarter of the annual revenues of Tunisian tourism. Egypt, struck in 2005 after the massacre in Sharm, the year after suffered an $8 \%$ reduction in foreign tourist arrivals. Time also calculated the recovery time from the tragedies of the last decade. New York took 34 months after 11 September 2001 to return to the pre-2001 hotel attendance rate. Madrid and London, under attack in 2004 and 2005, were faster and it took a year" (Walsh, 2015).

Safety and security are so vital in tourism that the success of tourist investments depends on being able to provide safe and secure destinations. Terrorist attacks against tourist sites and tourism infrastructures have long been acknowledged as having significant effects on tourism and travel behaviour.

In global tourism, security and safety have become complex issues with a wide range of components including consumer protection, legal protection of tourists, environmental security, disaster protection, data safety, personal safety in communication, quality assurance of services, and so forth (Kôvári \& Zimányi, 2011; Lambin, 2002).

$\square$ "In the weeks following the September 11 attacks in New York and Washington, passengers abandoned airports in their numbers as the effects of these attacks extended beyond U.S. borders with grave ramifications for many airlines. Soon after 11 September 2001, a number of airlines collapsed. Most shocking of all was the fact that a number of these airlines had been in existence for decades, and were not all American carriers. These attacks, along with the Gulf Wars, the war in Afghanistan and the terrorist attacks in Bali, have increasingly served to place tremendous and crucial importance on issues of traveller safety” (Johnson, 2004).

From a general point of view, the adoption of safety measures and security policies will likely cease to find political support once the perceived terrorist threat receives less attention in the media, and relatedly, the voting public (Hall, 2002).

From a management point of view, safety and security are not similar terms, but indicate different conditions and policies that corporations must adopt to contrast external negative events, such as terrorist crises. 


\section{Global Tourism, Safety Management and Security Management}

The external negative events affecting the global tourism industry can be classified according to cases without human involvement or natural situations (hurricanes, earthquakes, etc.) or cases with human involvement (industrial accidents, plane crashes, terrorist events, etc.) (Sausmarez, 2007; Seymour \& Moore, 2000).

With specific reference to global tourism, the classification of external negative events can be further qualified with regard to the probability of repetition of a given negative event (in the same geographic location), thus defining different degrees of probability of the occurrence of the event, such as terrorist attacks, natural disasters, political instability, wars, and epidemics diseases.

$\square$ The terrorist attacks in New York City and Washington D.C. on 11 September 2001 were followed by the Bali bombings on 12 October 2002; 5 explosions on Western and Jewish tourists on 16 May 2003 in Casablanca (Morocco); truck loaded with explosives against the synagogue on 11 April 2002 in Djerba (Tunisia); truck loaded with explosives against the Italian Carabinieri on 12 November 2003 in Nasiriyah (Afghanistan); truck loaded with explosives against two synagogues on 15 November 2003 in Istanbul (Turkey); twin bombings against British bank HSBC and the British Consulate on 20 November 2003 in Istanbul (Turkey); terrorist attacks on the local rail network on 11 March 2004 in Madrid (Spain); taking of 50 hostages in The Oasis residential complex on 30 May 2004 in Al-Khobar (Saudi Arabia); school massacre on 3 September 2004 in Beslan (Russia); massacre of Western tourists at the Hilton Hotel on 7 October 2004 in Tabe (Egypt); suicide attacks on the transport network on 7 July 2005 in London (UK); suicide attacks against tourists on 23 July 2005 in Sharm-el-Sheikh (Egypt); suicide attacks against tourists on 2 October 2005 in Kuta and Jimbaran (Bali); 10 attacks on luxury hotels, train stations and tourist on 26 November 2008 in Mumbai (India); attack on Westgate Mall on 21 September 2013 in Nairobi (Kenya); attack on the Jewish Museum on 24 May 2014 in Brussels (Belgium); massacre at the satirical magazine publisher Charlie Hebdo on 7 January 2015 in Paris (France); attack on the Hypercacher kosher supermarket on 10 January 2015 in Paris (France); attack on a conference on Islam on 14 February 2015 in Copenhagen (Denmark); massacre of tourists at the Bardo Museum on 18 March 2015 in Tunis (Tunisia); massacre of students on 2 April 2015 in Nairobi (Kenya); massacre on the beach on 26 June 2015 in Sousse (Tunisia); attack on the peace march on 10 October 2015 in Ankara (Turkey); seven chain attacks on 13 November 2015 in Paris (France); attack on hotel on 20 November 2015 in Bamako (Mali).

In particular, terrorist attacks are focused on the worldwide tourism industry, but the real effects of these human involvements occur in a single destination 
(especially in places with significant investments in the global tourism industry and with high probability of disaster repeatability).

In other words, the global and local media emphasize the negative external events with the violence of a 'burst' effect that spreads rapidly across large portions of the planet, but ends just as quickly. Conversely, the same external event can profoundly strike the image of a destination (with longer-lasting negative effects), and above all, can change the global and long term investment policies of tourism corporations.

Terrorist incidents and all other threats to personal safety (whether human or natural disasters) lead global tourism management (and usually also the local authorities responsible for tourism) to adopt several measures to provide a higher level of tourist security and safety. These measures, which can be temporary or permanent, define safety management procedures that are positive and preventive (i.e., protective measures) and security management procedures that are temporary, locally tailored, and focused on specific problems.

With safety management, the negative consequences of general incidents can be moderated if all parties involved in a local tourism industry are prepared in confronting such incidents. Thus, crisis preparation is today an integral component of global tourism business practice, but many global (and local) tourism executives seem reluctant to anticipate operational solutions for possible crises. By contrast, global tourism managers very often specifically attend to security management plans as an ongoing process of developing organizational capabilities to prevent, contain, and recover from crises, chiefly for high-risk activities linked to the tourism business, such as airlines, coastal shipping, etc.

Safety and security measures are quite different and both are employed by global tourist managers (and by local tourism authorities).

A basic principle of safety, for example at a hotel, is that guests are primarily responsible for their own security.

Global tourism safety management and global tourism security management concern many areas and problems. The following list is not exhaustive, but merely a suggested approach to focus on key tourist safety and security management problems.

\section{GLOBAL SAFETY \& SECURITY MANAGEMENT KEY ISSUES}

\section{TOURISM SAFETY}

Tourist Safety

Hotel Safety

Safety-Seeking Travellers

Travellers

Safety of Tourism Facilities

Food Safety Precautions

Security

\section{TOURISM SECURITY}

Tourist Security

Hotel Security

Security \& Protection of

Security of Outgoing Travellers

Visitor's Personal 
Site (Destination) Safety

Safety Standards

Hotel International Fire Safety Practices

Fire Safety Codes \& Regulations

Measures

Traffic Safety

Public Safety

Safety of Maritime Navigation

Public Safety Requirements

Safety Colours \& Safety Signs (ISO 3864:1984)

Safety Alarms \& Devices
Security Legislation

Security Agreements

Aviation Security Conventions

Air Transport Security

Airport Security Measures

Control of Security

Security Personnel

Private Security Companies

Visible \& Invisible Security

Data Bases on Security \& Risks

Protection of visitors/tourists from locals and other visitors.

Tourist Safety Tourists who stay in a hotel at any destination can be vulnerable to robbery, assault, rape, larceny, and fire.

$\square$ Tourist Security. An effective security system requires well-trained personnel to carry out the security procedures accordingly and to operate the security equipment properly. A comprehensive training program should include the protection of guests, the general public, and employees.

Protecting visitors/travellers from the tourism industry itself. The airline industry is a good example of this problem. Visitors are often moved from counter to counter, given misinformation.

Protecting staff. Tourism safety programs to ensure the protection of staff members working in hotels, restaurants, etc. from visitors.

$\square$ Security Personnel. The human element is usually cited as the most important factor in security. A typical security department in a hotel consists of a security manager, security officer, security guards, timekeepers and doormen. The structure, size, and reporting level of a security department varies from hotel to hotel.

Site protection. Local sites, attractions, museums, hotels, etc., are often abused by visitors. A good tourism safety program examines the physical environment and matches it with the type of visitors who use it. Site protection needs may change 
during different periods of the year. For example, a beach community may attract many young college students during spring break, but switch to family-oriented vacations in other seasons.

$\square$ Destination (Site) Safety. Tourist sites are defined as systems composed of accommodation facilities, attractions, and transport.

Protecting the destination's image. It can take years to regain a good reputation after a major crime spell, health disaster, or environmental crisis. It is less expensive to prevent a tourism crisis than to recover the destination's reputation (Gnecchi, 2009; Brondoni, 2008). At the national level, the political parties should provide law enforcement against crime and protect tourists.

Safety of Tourism Facilities. Hotel Associations (HA) and hotel security committees should be formed for security consciousness through regular meetings and discussions among hotel members. HA and police committees should meet bimonthly hosted by different hotels on a rotation basis.

$\square$ Safety-Seeking Travellers. National and local laws should protect tourists against crimes at the destination level.

Protecting a destination from risk. A tourism security program entails not only security and safety issues, but is also focused on risk management, which is an important aspect of tourism safety and security. Preventing a negative incident is more important than recovering from an incident and can avoid expensive litigation and legal fees. At the industry level, hotel associations should take an active role in facilitating and coordinating security and safety activities.

\footnotetext{
$\square$ "The Singapore Hotel Association and the Police Department conduct various security courses or seminars for all hotel employees concerned. The security managers maintain a very close working relationship police. They meet regularly to exchange ideas on crime trends, crime statistics or situations that are affecting the hotel industry. The police would provide the managers with crime prevention advice during the meetings too. They also help the hotels by evaluating their security systems" (Chiang, 2000).
}

Thus, the vulnerability of tourism to external negative events, such as tourism terrorism, defines the growing importance of tourism safety and security management in a global approach as an integral part of the tourism industry's operations (Prideaux, Laws \& Faulkner, 2003; Faulkner, 2001; Faulkner \& Vikulov, 2001), emphasising the need for more information and a conceptual framework "to structure the cumulative development of knowledge about the impacts of, and effective responses to, external negative events" (Ritchie, 2004).

The globalisation of the tourism industry and the world's communication interdependence define a new reality for the tourism industry, where negative 
events that occur in a tourism destination can affect tourism activities around a broader area or even worldwide (Brondoni, 2011).

Tourism attention to negative external factors and the fact that many tourism destinations are increasingly dependent on global tourism for their growth and survival creates increasing pressure on tourism managers and planners to develop strategies to deal with the impacts of negative events, crises and disasters to protect the tourism business.

\section{Bibliography}

Adejuwon, F. (1996). Globalisation of Tourism and its Effects on Africa with Special Regard to Nigeria, in Keller, P. (ed.), Globalisation and Tourism, AIEST, St. Gallen.

Apostolopoulos, Y., \& Sönmez, S. (2000). New Directions in Mediterranean Tourism: Restructuring and Cooperative Marketing in the Era of Globalization, Thunderbird International Business Review, 42, (4), 381-392.

Bellini, N. (2004). Territorial Governance and Area Image, Symphonya. Emerging Issues in Management (symphonya.unimib.it), 1, 14-26.

http://dx.doi.org/10.4468/2004.1.03bellini

Brackenbury, M. (1996). New Opportunities for the Mediterranean, Inter-Ministerial Tourism Conference "Marketing the Mediterranean as a Region", November 7-9, Sliema, Malta.

Brondoni, S. M. (2016). Global Tourism Management. Mass, Experience and Sensations Tourism, Symphonya. Emerging Issues in Management (symphonya.unimib.it), 1, 7-24.

http://dx.doi.org/10.4468/2016.1.02brondoni

Brondoni, S. M. (2015). Global Networks, Outside-In Capabilities and Smart Innovation, Symphonya. Emerging Issues in Management (symphonya.unimib.it), 1, 6-21.

http://dx.doi.org/10.4468/2015.1.02brondoni

Brondoni, S. M. (2014), Global Capitalism and Sustainable Growth. From Global Products to Network Globalisation, Symphonya. Emerging Issues in Management (symphonya.unimib.it), 1, $10-31$

http://dx.doi.org/10.4468/2014.1.02brondoni

Brondoni, S. M. (2012). Innovation and Imitation: Corporate Strategies for Global Competition, Symphonya. Emerging Issues in Management (symphonya.unimib.it), 1, 10-24.

http://dx.doi.org/10.4468/2012.1.02brondoni

Brondoni, S.M. (2011).Global Networks, Knowledge Management and World Cities, Symphonya. Emerging Issues in Management (symphonya.unimib.it), 1, 7-18

http://dx.doi.org/10.4468/2011.1.02brondoni

Brondoni, S. M. (2008). Market-Driven Management, Competitive Space and Global Networks, Symphonya. Emerging Issues in Management (symphonya.unimib.it), 1, 14-27. http://dx.doi.org/10.4468/2008.1.02brondoni

Chiang, L. C. (2000). Strategies for Safety and Security in Tourism. A Conceptual Framework for the Singapore Hotel Industry, The Journal of Tourism Studies, 11 (2), December, 44-52.

Clift, S., \& Page, S. (2015). Health and the International Tourist, Routledge, London.

Coles, T., \& Hall, C. M. (eds) (2008). Tourism and International Business, Routledge, London.

Cooper, C., \& Hall, C. M. (2013). Contemporary Tourism: An International Approach, 2nd ed., Goodfellow, Oxford.

Day, G. (2001). Market Driven Winners, Symphonya. Emerging Issues in Management (symphonya.unimib.it), 2, 12-22.

http://dx.doi.org/10.4468/2001.2.02day 
Dwyer, L., Edwards, D., Mistilis, N., Scott, N., \& Cooper, C. (2008). Megatrends Underpinning Tourism to 2020: Analysis of Key Drivers for Change, CRC for Sustainable Tourism, Pty Ltd, Sydney.

Faulkner, B. (2001). Towards a Framework for Tourism Disaster Management, Tourism Management, 22, 135-147.

Faulkner, B., \& Vikulov, S. (2001). Katherine, Washed Out One Day, Back on Track the Next: A Post-Mortem Of A Tourism Disaster, Tourism Management, 22, 331-344.

Gnecchi, F. (2009). Market-Driven Management, Market Space and Value Proposition, Symphonya. Emerging Issues in Management (symphonya.unimib.it), 2, 33-45.

http://dx.doi.org/10.4468/2009.2.04gnecchi

Gössling, S., \& Hall, C. (eds) (2006). Tourism and Global Environmental Change, Routledge, London.

Grant, R. M., \& Baden-Fuller, C. (2004). A Knowledge Accessing Theory of Strategic Alliances, Journal of Management Studies, (41), 1, 61-84. http://doi:10.1111/j.1467-6486.2004.00421.x

Hall, M.C. (2002). Travel Safety, Terrorism and the Media: The Significance of the Issue-Attention Cycle, Current Issues in Tourism, 5 (5), 458-466.

http://dx.doi.org/10.1080/13683500208667935

Heath, E. (2001). Globalisation of the Tourism Industry: Future Trends and Challenges for South Africa, SAJEMS NS, (4) 3, 542-569.

Holmes, D., (ed.) (2001). Virtual Globalization: Virtual Spaces/Tourist Spaces, Routledge, London.

Johnson, J. R. (2004). Safety and Security in the Tourism Industry - A Regional Perspective on Tourism Security, Caribbean Tourism Organization.

Keller, P. (1996). Globalisation of Tourism, AIEST, St Gallen.

Kôvári, I., \& Zimányi, K. (2011). Safety and Security in the Age of Global Tourism (The Changing Role and Conception of Safety and Security in Tourism), Applied Studies in Agribusiness and Commerce, 5, 59-61.

Lambin, J. J. (2002). Strategic Marketing Revisited after September 11, Symphonya. Emerging Issues in Management (symphonya.unimib.it), 1, 7-27.

http://dx.doi.org/10.4468/2002.1.02lambin

Mazilu, M., \& Marinescu, R. (2008). Excellency or Chaotic Globalization in Tourism? Annals of the University of Oradea, Economic Science Series, 17 (2), 699-702.

McIntosh, R. W., Goeldner, C. R., \& Ritchie, J. R. B. (2009). Tourism: Principles, Practices and Philosophies (11th ed.) John Wiley \& Sons, New York.

Page, S. J. (2015). Tourism Management, $5^{\text {th }}$ ed., Routledge, London.

Poon, A. (1993). Tourism, Technology and Competitive Strategies, International, Wallingford.

Prideaux, B., Laws, E., \& Faulkner, B. (2003). Events in Indonesia: Exploring the Limits to Formal Tourism Trends Forecasting Methods in Complex Crisis Situations, Tourism Management, 24, 475-487.

Ritchie, B. W. (2004). Chaos, Crises and Disasters: A Strategic Approach to Crisis Management in the Tourism Industry, Tourism Management, 25, 669-683.

Salvioni, D. M. (2016). Hotel Chains and the Sharing Economy in Global Tourism, Symphonya. Emerging Issues in Management (symphonya.unimib.it), 1, 31-44.

http://dx.doi.org/10.4468/2016.1.04salvioni

Salvioni, D. M. (2010). Intangible Assets and Internal Controls in Global Companies, Symphonya. Emerging Issues in Management (symphonya.unimib.it), 2, 39-51.

http://dx.doi.org/10.4468/2010.2.4salvioni

Salvioni, D. M. (2008). Market-Driven Management and Corporate Governance, Symphonya.

Emerging Issues in Management (symphonya.unimib.it), 2, 13-27.

http://dx.doi.org/10.4468/2008.2.02salvioni 
Salvioni, D. M., Astori R. (2013). Sustainable Development and Global Responsibility in Corporate Governance, Symphonya. Emerging Issues in Management (symphonya.unimib.it), 1, 28-52.

http://dx.doi.org/10.4468/2013.1.03salvioni.astori

Sausmarez, N. (2007). Crisis Management, Tourism and Sustainability: The Role of Indicators, Journal of Sustainable Tourism, 5 (6), 700-714.

Seymour, M., \& Moore, S. (2000). Effective Crisis Management: Worldwide Principles and Practice, Cassell: London.

Tisdell, C. A. (2004). Tourism Development as a Dimension of Globalisation: Experiences and Policies of China and Australia, The University Of Queensland, May, Working Paper No. 31.

Tisdell, C. A., \& Clevo, W. (2012). Nature-Based Tourism And Conservation: New Economic Insights And Case Studies, Edward Elgar Publishing, Cheltenham.

Vanhove, N. (1996). Globalisation of Tourism Demand: The Underlying Factors and the Impact on Marketing Strategy, in Keller, P. (ed.), Globalisation and Tourism, St. Gallen, AIEST.

Walsh, D. (2015). Tunisia Beach Terror Attack will Cost Tour Operator up to €40m, The Times, August 14.

Zillman, C. (2015). Terrorirism's Effect on Tourism Doesn'n Last Very Long, Fortune, November 30 . 